\title{
Influence of Corporate Social Responsibility and Corporate Culture to The Strategic Alignment Maturity, Business Performance and Corporate Sustainability at the Consumer Service
}

\author{
Muhammad Syarif \\ Faculty of Economic and Business \\ University of Trunojoyo Madura \\ Bangkalan, Indonesia \\ muhammadsyarif_utm@yahoo.co.id
}

\begin{abstract}
This study explains that, corporate social responsibility has a significant effect on Strategic Alignment Maturity with the direction of positive relationships, corporate social responsibility has a significant effect on business performance with the direction of positive relationships, corporate culture has a significant effect on strategic alignment maturity with the direction of positive relationships, influential corporate culture significant to business performance with the direction of positive relationship, strategic alignment maturity has a significant effect on business performance with the direction of positive relationship, strategic alignment maturity has a significant influence on the sustainability of the company with the direction of positive relationships, and business performance has a significant effect on the sustainability of the company in the direction of positive relationships, corporate social responsibility have a significant effect on the sustainability of the company with the direction of positive relationships, and the corporate culture has a significant effect on the sustainability of the company in the direction of a positive relationship.
\end{abstract}

Keywords-Corporate Social Responsibility, Corporate Culture, Strategic Alignment Maturity, Business Performance and Corporate Sustainability

\section{INTRODUCTION}

Businessmen at the global business era at present are getting more aware that sustainability of their business is not merely focused on the efficiency in utilizing the resources to gain the profit. Without being accompanied by the effort to improve quality of their social interaction to their external environment in the form of Corporate Social Responsibility (CSR) and the Environmental Sustainability, the company operation will sooner or later undergo the problem. CSR is an expression of companies in microeconomic policies for future development [1]. This effort is to reconcile socio-economic development with regard to the corporate environment as a valuable legacy for future generations. There is now a lot of literature that addresses the definition of CSR. Some circles claim that CSR has a significant positive contribution to competitiveness

The corporate sustainability becomes the focus in this study considering the fact that the company able to carry out its sustainable business operation has proven that it has been able to deal with the global business competition at present. The corporate sustainability is a business approach establishing long term values for the stakeholders by embracing the opportunities and managing the risks deriving from economy, social and environmental developments. Based on some previous researches, the antecedent variables influencing the corporate sustainability variables in this study are: CSR (Corporate Social Responsibility), corporate culture, SAM (Strategic Alignment Maturity), and the business performance. Output of study by Siegel and Paul indicates that CSR activities have productive significant impacts to efficiency, technical changes, and economic scale of the company [2].

The corporate sustainability can be achieved if the company has a corporate culture able to lead the organizational behavior to adapt to the external environment and to make the internal integration. Corporate culture is able to help the company reach the success. Work culture holds the important role in establishing sustainability for an organization. Corporate culture is a set of values, norms, rites and patterns of behavior becoming characteristics of the company. SAM is a harmonization process between the objectives as well as the information technology and the business goals of an organization, a process how to make the information technology able to run in parallel with business and so is the contrary, how to make the business in line with the information technology. Performance is a complex multidimensional construct with many differences in the sense that it depends on who is evaluating, how it is evaluated, and what aspects are evaluated. The business performance instrument with the orientation to the consumer service applied in this study refers to Bonnici and Sarkis [3].

This template, modified in MS Word 2007 and saved as a "Word 97-2003 Document" for the PC, provides authors with most of the formatting specifications needed for preparing electronic versions of their papers. All standard paper components have been specified for three reasons: (1) ease of use when formatting individual papers, (2) automatic compliance to electronic requirements that facilitate the concurrent or later production of electronic products, and (3) conformity of style throughout a conference proceedings. Margins, column widths, line spacing, and type styles are builtin; examples of the type styles are provided throughout this document and are identified in italic type, within parentheses, 
following the example. Some components, such as multileveled equations, graphics, and tables are not prescribed, although the various table text styles are provided. The formatter will need to create these components, incorporating the applicable criteria that follow.

\section{RESEARCH METHODS}

This study aims to explain the influence of corporate social responsibility and corporate culture on the strategic alignment of maturity, business performance and sustainability of the company. Analysis using Partial Least Square (PLS) to test the significance of the research variables. Data was taken from the head of the office of the Unit Consumer Service (UCS) PT. Indonesian Telecommunications Regional V East Java by using saturated sampling, ie all populations used as samples. The number of respondents is 70 respondents. Questionnaires (main instruments), interviews, observations, and strong documentaries in collecting data.

\section{RESULTS AND DISCUSSION}

Data processing and testing using the PLS get the outputs as follows: the Structural Equation as shown in Figure 1. and output of the Linear Coefficient Testing as shown in Table 1. below.

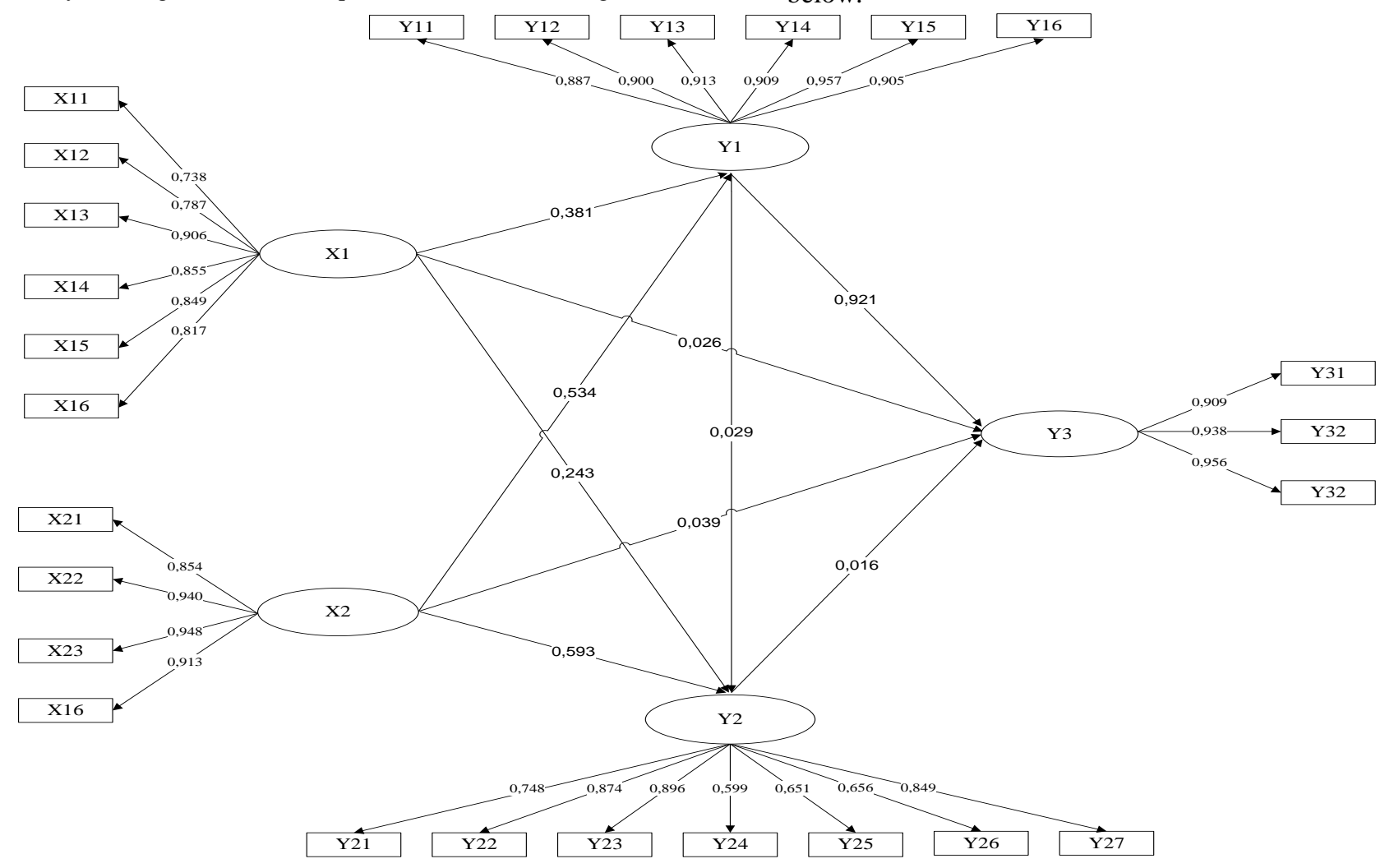

Fig. 1. Exogenous Relation to Endogen

TABLE I. OutPut of Linear CoefFicient Testing ON THE Model

\begin{tabular}{|c|c|c|c|c|}
\hline Variables & Coefficient & T Statistics & T Table & Information \\
\hline Corporate Social Responsibility $\left(\mathrm{X}_{1}\right) \rightarrow$ Strategic Alignment Maturity $\left(\mathrm{Y}_{1}\right)$ & 0.381 & 21.472 & 1,96 & Significant \\
\hline Corporate Social Responsibility $\left(\mathrm{X}_{1}\right) \rightarrow$ Kinerja Bisnis $\left(\mathrm{Y}_{2}\right)$ & 0.243 & 14.461 & 1,96 & Significant \\
\hline Corporate Culture $\left(\mathrm{X}_{2}\right) \rightarrow$ Strategic Alignment Maturity $\left(\mathrm{Y}_{1}\right)$ & 0.534 & 28.241 & 1,96 & Significant \\
\hline Corporate Culture $\left(\mathrm{X}_{2}\right) \rightarrow$ Business Performance $\left(\mathrm{Y}_{2}\right)$ & 0.593 & 21.346 & 1,96 & Significant \\
\hline Strategic Alignment Maturity $\left(\mathrm{Y}_{1}\right) \rightarrow$ Business Performance $\left(\mathrm{Y}_{2}\right)$ & 0.029 & 2.154 & 1,96 & Significant \\
\hline Strategic Alignment Maturity $\left(\mathrm{Y}_{1}\right) \rightarrow$ Corporate Sustainability $\left(\mathrm{Y}_{3}\right)$ & 0.921 & 67.737 & 1,96 & Significant \\
\hline Business Performance $\left(\mathrm{Y}_{2}\right) \rightarrow$ Corporate Sustainability $\left(\mathrm{Y}_{3}\right)$ & 0.016 & 2.192 & 1,96 & Significant \\
\hline Corporate Social Responsibility $\left(\mathrm{X}_{1}\right) \rightarrow$ Corporate Sustainability $\left(\mathrm{Y}_{3}\right)$ & 0.026 & 2.655 & 1,96 & Significant \\
\hline Corporate Culture $\left(\mathrm{X}_{2}\right) \rightarrow$ Corporate Sustainability $\left(\mathrm{Y}_{3}\right)$ & 0.039 & 4.052 & 1,96 & Significant \\
\hline
\end{tabular}

From the suitable model, each linear coefficient can be interpreted. Such linear coefficients constitute the hypotheses in this research that can be presented in structural equations as follows:

$\mathrm{Y}_{1}=0.381 \mathrm{X}_{1}+0.534 \mathrm{X}_{2}$
$\mathrm{Y}_{2}=0.243 \mathrm{X}_{1}+0.593 \mathrm{X}_{2}+0.029 \mathrm{Y}_{1}$

$\mathrm{Y}_{3}=0.026 \mathrm{X}_{1}+0.039 \mathrm{X}_{2}+0.921 \mathrm{Y}_{1}+0.016 \mathrm{Y}_{2}$

Based on the data shown in Table-1, it is known that all variable relations materialized in 9 (nine) hypotheses have significant influence leading to positive relationship. 


\section{A. Influence of Corporate Social Responsibility to the Strategic Alignment Maturity}

Corporate social responsibility has significant influence to the strategic alignment maturity leading to positive relationship. This is shown from the linear coefficient having the positive sign at the amount of 0.381 with the T-statistic value of 21.472 bigger than the $\mathrm{T}$-table $=1.96$. It means that the implementation of corporate social responsibility program can give contribution to the criteria of skill in the strategic alignment maturity, namely condition of company social environment. This is caused by facts that the CSR activities have direct or indirect relation with the needs and interests of the stakeholders (company social environment). CSR becomes the business strategy that can be maximized in order to increase the positive image of the company. CSR activity can be a beneficial element as a corporate strategy, contributing to risk management and maintaining relationships that can provide long-term benefits for the company [4]. CSR activities have a significant productive impact on efficiency, technical change, and the economic scale of the company [2].

\section{B. Influence of Corporate Social Responsibility to the Business Performance}

.The corporate social responsibility has significant influence to the business performance, leading to positive relationship. This is indicated by the linear coefficient having the positive sign at the amount of 0.243 with the T-statistic value of 14.461 bigger than the $\mathrm{T}$-table $=1.96$. It means that the corporate social responsibility has significant influence to the business performance. This means that if the company carries out the true real and sustainable corporate social responsibility activities by maximizing the positive impacts and at the same time minimizing the negative impacts of certain business activities, the company will be able to enjoy good market performance and in turn will also be able to be enjoyed by the stakeholders. Implementation of corporate social responsibility will establish the increase in trust and image of the stakeholders, so that able to give contribution in materializing the increase of the company performance.

The findings of this study support the results of the study by Lako, explaining that one advantage that will be achieved by companies that practice CSR in a sustainable manner, namely profitability and financial performance will be more robust [5]. Then confirmed by Chad, which concluded that the implementation of CSR contributes to the realization of company performance, the better the CSR implementation the higher the company's performance [6]. This is supported by several other studies, namely Branco et. al., [7], and R. Edward Freeman [8].

\section{Influence of Corporate Culture to the Strategic Alignment Maturity}

Corporate culture has significant influence to the strategic alignment maturity, leading to positive relationship. This is shown by the linear coefficient having the positive sign at the amount of 0.534 with the T-statistic value of 28.241 bigger than the $\mathrm{T}$-table $=1.96$. It means that the more number of company employees accept the core values taken by the company and feel so much bound to them, the easier a strategy to be implemented in a company, because the alignment level of perception in the applicable corporate culture is significantly related to the alignment level of the strategy. The cultural adjustability level contributes the major amount of variants at the level of strategic alignment maturity. Corporate culture has a potential to give contribution to the optimal achievement supporting the alignment level between the business strategy and the information technology. The findings of this study support the results of Kaplan [9] and Niven [10], that every company has a culture to run its company. The culture that supports the strategy will influence the implementation of the strategy.

\section{Influence of Corporate Culture to the Business Performance}

Corporate culture has significant influence to the business performance, leading to positive relationship. This is indicated by the linear coefficient having the positive sign at the amount of 0.593 with the T-statistic value of 21.346 bigger than the $\mathrm{T}$-table $=1.96$. It means that the corporate culture significantly influences the business performance. The meaning is that the higher the characteristics of the corporate culture is, the more conducive the corporate culture to be in forming the positive behavior (high performance), because corporate culture constitutes a system of meaning and the joint control followed by members of the company. Involvement in cultural context is the empowerment of culture as the actualization of ability to develop every employee independently, the company organizes the work activities for the team and develop the employees capability to achieve the maximum results. The findings of this study support the opinion of Robbins explaining that organizational culture is a system of meaning and joint control adopted by members that distinguishes its organization from other organizations [11].

\section{E. Influence of Strategic Alignment Maturity to the Business Performance}

Strategic Alignment Maturity has significant influence to the business performance, leading to positive relationship. This is shown by the linear coefficient having the positive sign at the amount of 0.029 with the T-statistic value of 2.154 bigger than the $\mathrm{T}$-table $=1.96$. It means that the available alignment between the information system and the business unit is able to support and improve business performance of the company. Through the alignment between the information system plan and the business plan, the information resources will support the business goal and gain the profit in grabbing the opportunities in order to utilize the information system strategy. Strategic Alignment means the conformance between priority and activities of information system function and business unit. The goals of strategic alignment are: priority, ability, decision and information system action in order to support the whole business.

The findings of this study support Chan et. al., states that companies that appear to do their best are companies where there is alignment between business strategy and realizing the 
information system strategy [12]. Luftman and Brier argue that companies that have achieved alignment can build strategic competitive advantages that will provide them with increased visibility, efficiency, and profitability to compete in today's changing markets [13].

\section{F. Influence of Strategic Alignment Maturity to the Corporate Sustainability}

Strategic Alignment Maturity has significant influence to the Corporate Sustainability, leading to positive relationship. This is indicated by the linear coefficient having the positive sign at the amount of 0.921 with the T-statistic value of 67,737 bigger than the $\mathrm{T}$-table $=1.96$. It means that the company which is successful in performing the integration between information technology and the business strategy shows the significant increase in its income. Alignment of business strategy and the information technology is applied by the company to increase the efficiency, to reduce the costs, to create the constraints to new comers, to improve relationship between consumers and suppliers, and to establish products and solution of new business in achieving the company sustainability. Strategy in developing the information technology shall have the alignment with the business strategy run by the company. The findings of this study support the research of Tarafdar and Qrunfleh, tactical IT-business alignment is needed to ensure that IT projects are implemented on time and applications are implemented providing planned and desired business benefits [14].

\section{G. Influence of Business Performance to the Corporate Sustainability}

Business Performance has significant influence to the Corporate Sustainability, leading to positive relationship. This is shown by the linear coefficient having the positive sign at the amount of 0.016 with the T-statistic value of 2.192 bigger than the $\mathrm{T}$-table $=1.96$. It means that the business performance significantly influences the corporate sustainability. The business performance in this study is nonfinancial performance, namely service performance to the customers. Measurement of customer service performance can be used as material for evaluation by the manager to know the problems early and able to measure the customer-oriented indicators.

Findings from the results of this study support the opinion of Gompers et. al., showing that improving corporate governance has a greater influence on the company's financial performance than the absolute level of corporate governance performance [15]. The findings of this study also support the opinion of Schaltegger et. al., this study is able to show the significant effects of policy, strategy and operations sustainability on both the impact of sustainability and financial performance [16].

\section{H. Influence of Corporate Social Responsibility to the Corporate Sustainability}

Corporate Social Responsibility has significant influence to the Company Sustainability, leading to positive relationship. This is indicated by the linear coefficient having the positive sign at the amount of 0.026 with the T-statistic value of 2.655 bigger than $\mathrm{T}$-table $=1.96$. It means that the CSR program constitutes the company commitment to support the establishment of company sustainability. Application of CSR program is one of the forms of implementation of the concept of good company governance. CSR program constitutes commitment of the company to support the establishment of corporate sustainability.

Hart and Milstein, argue that organizations need to consider their exposure to social and environmental activities, not only in the present, but also in the future, as a means to produce sustainable value [17]. Folmer and Tietenberg stated that corporate sustainability is an organizational commitment to corporate sustainability can be seen as a new and developing company management paradigm [18].

\section{Influence of Corporate Culture to the Corporate Sustainability}

Corporate Culture has significant influence Corporate Sustainability, leading to positive relationship. This is shown by the linear coefficient having the positive sign at the amount of 0.039 with the T-statistic value of 4.052 bigger than $\mathrm{T}$-table $=1.96$. It means that the corporate culture influences the way the employees understand and apply the company sustainability. An organization dominated by culture will place bigger emphasis on efficiency of resources in striving for the company sustainability. The findings of this study support that the opinion of Peteraf [19] and Porter, [20], organizations dominated by an internal process culture will place greater emphasis on the economy, performance growth and long-term benefits in pursuing corporate sustainability.

\section{CONCLUSION}

Corporate social responsibility has significant influence to the strategic alignment maturity leading to positive relationship, corporate social responsibility has significant influence to the business performance leading to positive relationship, corporate culture has significant influence to the strategic alignment maturity leading to positive relationship, corporate culture has significant influence to the business performance leading to positive relationship, strategic alignment maturity has significant influence to the business performance leading to positive relationship, strategic alignment maturity has significant influence to the corporate sustainability leading to positive relationship, and business performance has significant influence to the corporate sustainability leading to positive relationship, the corporate social responsibility has significant influence to the corporate sustainability leading to positive relationship, and the corporate culture has significant influence to the corporate sustainability leading to positive relationship.

In general, the important finding of this study is that it gives theoretical contribution to the analysis in strategy management and organizational behavior in telecommunication industry in performing the empirical research on the corporate sustainability, namely the conformance or alignment of corporate social responsibility, corporate culture and its influence to the strategic alignment 
maturity, business performance and company sustainability. The role of strategic alignment maturity is so strong, and on the other hand the role of business performance is so weak in achieving the corporate sustainability.

In general as the important finding for the company policy is that the highest values of loading factors cover: the employment practice in corporate social responsibility, adaptability to corporate culture, scope and architecture in strategic alignment maturity, customer visit in business performance and the economic dimension in company sustainability. Meanwhile, the lowest value of loading factors among others are the company governance in corporate social responsibility, involvement of employee in corporate culture, communication between business unit and information technological unit in strategic alignment maturity, calls/contacts to customers having the low purchase criteria in business performance and environmental dimension in corporate sustainability.

Based on the outputs of validation or proving on the nine hypotheses, a conclusion can be made in integrated way that the influence of corporate social responsibility and corporate culture simultaneously through the strategic alignment maturity can achieve the company sustainability. The influence of corporate social responsibility and corporate culture simultaneously through the business performance can establish the corporate sustainability.

\section{REFERENCES}

[1] Simen, S. F., \& Ndao, A. (2013). L'effet de la mise en place d'une stratégie de Responsabilité Sociale de l'entreprise sur la culture organisationnelle: Analyse, implications et enjeux pour le Sénégal. Revue Congolaise de Gestion, (1), 131-170.

[2] Siegel, Donald S., and Paul, Catherine J. M. 2006. Corporate Social Responsibily and Economic Performance, Springer Science and Business Media, LLC, J Prod Anal 26, p. 207-211.

[3] Bonnici, Tanya Sammut, and Sarkis, Joseph. 2001. Performance Measurement Systems Development in a Telecommunication Company, Production and Inventory Management Journal. January 1, 2001
[4] Heal, Geoffrey, dan Garret, Paul 2004. Corporate Social Responsibility, An Economic and Financial Framework, Columbia Business School, 2004.

[5] Lako, A. 2008. CSR Obligations and Reform of Business and Accounting Paradigms, Indonesian Management Businesses, No. 06 Th. XXXVII, 2008, Jakarta.

[6] Chad, M. 2006. The Relationship between Corporate Social Responsibility Performance and Corporate Financial Performance, Industry Type as Boundary Condition, The Business Review, Cambridge, September, 5, 1 .

[7] Branco, L. M., Hilário, M. O. E., \& Cintra, I. D. P. (2006). Perception and satisfaction with body image in adolescents and correlations with nutrition status. Archives of Clinical Psychiatry (São Paulo), 33(6), 292 296.

[8] Freeman, R. E. (1984). Strategic management: A stakeholder perspective. Boston: Pitman, 13.

[9] Kaplan, R. S., \& Norton, D. P. (2001). The strategy-focused organization. Strategy and Leadership, 29(3), 41-42.

[10] Niven, P. R. (2002). Balanced scorecard step-by-step: Maximizing performance and maintaining results. John Wiley \& Sons.

[11] Robbins, Stephen, P. 2003. Organizational Behavior, Indonesian Edition. Jakarta : PT. Indeks

[12] Chan, Y. E., S. L. Huff, D. W. Barclay, and D. G. Copeland. 1997. Business strategic orientation, information systems, strategic orientation, and strategic alignment. Information Systems Research 8 (2): 125-150.

[13] Luftman, J.M., and Brier, T. 1999. Achieving and Sustaining BusinessIT Alignment. California Management Review, 42(1). 109-122.

[14] Tarafdar, M., \& Qrunfleh, S. (2009). IT-business alignment: A two-level analysis. Information Systems Management, 26(4), 338-349.

[15] Gompers P, Ishii J, Metrick A. 2003. Corporate governance and equity prices. The Quarterly Journal of Economics February: 107-155

[16] Schaltegger S, Figge F. 2000. Environmental Shareholder Value: Economic Success with Corporate Environmental Management. EcoManagement and Auditing 7(1): 29-42

[17] Hart, S. L., and Milstein, M. B. 2003. Creating sustainable value Academy of Management Executive, 17(2): 56-69.

[18] Folmer, H., \& Tietenberg, T. (2005). Corporate Sustainability, he International Yearbook of Environmental and Resource Economics 2005/2006.

[19] Peteraf, M. A. (1993). The cornerstones of competitive advantage: A resource-based view. Strategic Management Journal, 14(3): 179-191.

[20] Porter, M.E. (1985). Competitive advantage: Creating and sustaining superior performance. New York, London: Free Press, Collier Macmillan. 